\title{
EXPERIMENTAL MILLING STUDIES ON HARDENED STEELS - A REVIEW
}

\author{
Claudiu Ionuț Malea ${ }^{1}$, Eduard Laurențiu Nițu ${ }^{2}$, Monica Daniela Iordache ${ }^{2}$, Alin Daniel Rizea ${ }^{2}$ \\ ${ }^{1}$ University of Pitesti, Regional Research and Development Center for Innovative Materials, Processes and Products for the \\ Automotive Industry (CRC\&D-Auto), Doaga Street, no.11, Romania \\ ${ }^{2}$ University of Pitesti, Mechanics and Technology Faculty, Manufacturing and Industrial Management Department
} (DFMI), Targul din Vale Street, no.1, Pitesti, Romania

Corresponding author: Claudiu Ionuț Malea, claudiu.malea@upit.ro

\begin{abstract}
Hardened steels have numerous applications in the construction of molds and dies due, in particular, to their outstanding thermo-mechanical characteristics, such as wear resistance and high stiffness, but especially dimensional stability at high temperatures. Machined surfaces are conditioned to have important tribological characteristics. Thus, a high quality of machined surfaces is achieved by milling processes with high cutting speeds. These types of processes even manage to replace grinding or electro-erosion machining processes with a solid electrode. The paper presents a review of experimental studies in recent years from industry and scientific research. Issues are outlined which justify the utility of machining hard metals by machining processes, with a focus on machining by milling processes. Starting from input parameters, such as technological parameters, blank material, cutting tool material and machining environment, their influence is analysed on output parameters, such as chip morphology, cutting tool wear and surface integrity.
\end{abstract}

Key words: hardened steels, hard milling, hard machining, cutting parameters, tool wear, surface integrity.

\section{INTRODUCTION}

Machining of hardened steels with hardness greater than 45 HRC by milling processes is predominantly used for the manufacture of various tools in general, but especially tools such as molds and dies with complex shapes. These include molds for injection molding of plastics, molds for injection molding of metal materials, molds used in forging machining, and dies used for stamping or powder forming.

For the machining of hard metals exceeding 45 HRC, milling technology systems (TS) must meet certain specific characteristics in order to be able to process such materials. The accelerated increase in productivity of milling technology numerical control systems (TNCS) leads to machining possibilities with complex kinematics, reducing the need for EDM or grinding machining, as shown in Figure 1.

Thus, technological systems support optimised machining processes with a significant reduction of machining operations and the use of tools with appropriate geometries and carefully selected materials, as well as the correct definition of cutting parameters. All this supports the use of highly efficient machining (HEM) systems. This concept combines the advantages of high speed machining (HSM), dry machining (DM) or hard machining (HM), as shown in Figure 2. The need for research in these directions is motivated by the elimination of costs related to the use of expensive machining environments, such as cooling- lubrication with various emulsions. These increase the cost of processing by up to $17 \%$, but reduce the costs related to the tools used by up to 4\% (Grzesik, 2017). Thus, there is a need to develop cutting tools and machining processes that eliminate such technological problems.

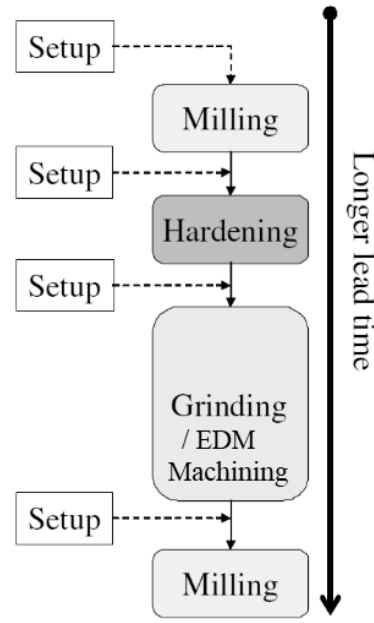

(a)

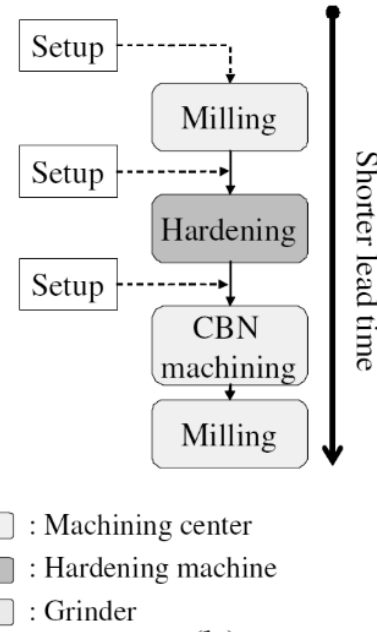

(b)
Fig. 1. Difference between technological processes: a) grinding/ EDM machining with solid electrode after heat treatment operations and b) hard metal milling directly after heat treatment operations (Soshi et al., 2013)

In milling processes of hardened steels, both the milling cutters and the blank material are subjected to high stresses. Thus, deformation speeds are in the order of $10^{4} \mathrm{~s}^{-1}$, and temperatures can have values 
close to $1000^{\circ} \mathrm{C}$.

In most of the literature, but also in the recommendations of hard metal working tool manufacturers, solutions are proposed for the implementation of technologies for such materials without cooling-lubrication or with heat supply. Therefore, machining is carried out in dry environments or at most with compressed air cooling, with the purpose rather of removing chips generated from the front of the tool. However, researchers are trying to find multiple solutions to increase tool life, in particular, but without significant negative effects that could occur on the surfaces of machined parts.

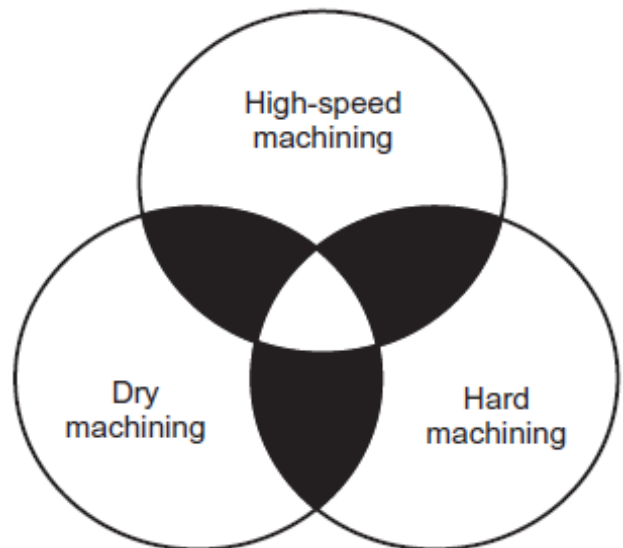

Fig. 2. Modern machining processes (Grzesik, 2017)

This paper presents a review of recent studies in which experimental research is carried out on the machining of hardened steels, with hardnesses exceeding $45 \mathrm{HRC}$, on technological milling systems. Some of the steels studied in the literature, specific aspects of the technological systems and processes used, and characteristics of the tools used are presented. The analysis starts from the parameters of the cutting conditions, aspects of chip formation, but also addresses elements of tool wear and durability or surface integrity.

\section{HARDENED STEELS}

In the field of machining, according to ISO 513:2012, materials that can be machined are classified into six categories. Among these materials, group $\mathrm{H}$ includes steels that can be delivered with hardnesses above 45 HRC directly from manufacturers. However, hard steels are not clearly classified, but it can be concluded that this category can include all metals and alloys which can be intentionally hardened by heat treatment operations of quenching and tempering to change their mechanical properties. Depending on their intended applications (Davis, 1989), hard materials can be classified according to American standards (AISI):
- Shock-resistant tool steels. Their carbon content is between $0.5-0.6 \% \mathrm{C}$, with alloying elements predominantly chromium, tungsten and molybdenum based. This also includes steels with alloying elements based on silicon and magnesium. Tempering operations are carried out in oil bath or water bath environments.

- Tool steels for cold working. They are used in industrial applications not exceeding $200^{\circ} \mathrm{C}$. Depending on the cooling environment used in tempering operations they are classified as: oil-bath cooled $(<1 \% \mathrm{C})$; open air cooled $(\approx 1 \% \mathrm{C})$; and high carbon and chromium $(1.4-2.11 \% \mathrm{C}$ and $12-14 \% \mathrm{Cr})$.

- Tempering water tool steels. These steels contain between $0.9-1 \% \mathrm{C}$, but also alloying elements based on chromium, tungsten and molybdenum.

- Tool steels for hot forming machining. These steels are used for hot forming applications where temperatures reach around $200-800^{\circ} \mathrm{C}$. They are divided into three main categories: chromiumbased $(<3.25 \% \mathrm{Cr})$; tungsten- based $(>9 \% \mathrm{~W})$; molybdenum- based $(>8 \% \mathrm{Mo})$. This category includes steels belonging to group $\mathrm{H}$ according to ISO 513:2012, shown in Table 1.

- High-speed tool steels. The carbon content of these steels is around $0.6 \% \mathrm{C}$, with chromium and cobalt contents of $4 \% \mathrm{Cr}$ and $5-12 \% \mathrm{Co}$. They fall into two broad categories, depending on the predominant alloying element in their composition: molybdenum-based; tungsten-based.

Hardened steels with hardnesses above 45 HRC have a number of important specific characteristics that make their use in the construction of moulds and dies extremely reliable. They have high hardness, very good stiffness and toughness and very good fatigue strength. They also maintain their integrity at high temperatures, resulting in good resistance to oxidation and corrosion, and their very good thermal conductivity allows them to be used in pre-heated forging dies.

Hard metals behave relatively different during machining processes. For example, tool steel X155CrVMo12-1 (AISI D2), which can have its hardness increased by heat treatment operations up to $62 \mathrm{HRC}$, has a very high resistance to mechanical shocks due to the presence of chromium in the microstructure, and the behaviour during machining operations for this type of alloy is similar to that of alloys with even higher hardnesses than this (Gaitonde et al., 2016). On the other hand, the alloy type X20Cr13 (AISI 420), which is a stainless steel but can be hardened up to $52 \mathrm{HRC}$, retains its stainless properties and tends to adhere to the clearance surface of cutting tools, generating the socalled Build-up edge (BUE). 
3. MILLING PROCESSES AND TECHNOLOGICAL SYSTEMS

\subsection{Milling processes}

Face milling processes are the most commonly used, being kinematically highly flexible and easy to apply on all conventional and numerically controlled milling systems. For the best possible stability of the machining process, it is important to use only 50- 80 $\%$ of the cutter diameter, the cutter axis should be

Table 1. Examples of steels which belong to group H materials according to ISO 513: 2012 (Die \& Mold, 2020)

\begin{tabular}{|c|c|c|c|c|c|}
\hline \multicolumn{2}{|c|}{ ISO } & \multicolumn{2}{|c|}{ Material group } & Hardness & Examples of steels in the standards DIN/ AISI, SAE \\
\hline \multirow{4}{*}{$\mathrm{H}$} & \multirow[b]{2}{*}{$\mathrm{H} 3$} & $\mathrm{H} 3.1$ & \multirow[b]{2}{*}{$\begin{array}{l}\text { Hardened } \\
\text { steel } \\
<55 \text { HRC }\end{array}$} & $\begin{array}{l}45-48 \\
\text { HRC }\end{array}$ & $\begin{array}{c}\text { 40CrMnMo7/-; 40CrMnMoS8-6/-; 48CrMoV6-7/-; X38CrMoV5-1/ } \\
H 11 ; \text { X40CrMoV51/ HI3; 54NiCrMoS6/-; 90MnCrV8/O2. }\end{array}$ \\
\hline & & $\mathrm{H} 3.2$ & & $\begin{array}{l}48-55 \\
\text { HRC }\end{array}$ & $\begin{array}{c}\text { X210Cr12/ D3; 48CrMoV6-7/-; X40CrMoV5-1/ H13; } \\
\text { X100CrMoV51/ A2; 81MoCrV42-16/ 613; X155CrVMo12-1/ D2; } \\
\text { 30WCrV17-2/-; 54NiCrMoS6/-; 55NiCrMoV6/ L6; 40CrMnNiMo8- } \\
\text { 6-4/ 40CrMnNiMo8-6-4; X45NiCrMo4/-; 90MnCrV8/ O2; X20Cr13/ } \\
\text { 420. }\end{array}$ \\
\hline & \multirow[b]{2}{*}{$\mathrm{H} 4$} & H4.1 & \multirow{2}{*}{$\begin{array}{l}\text { Hardened } \\
\text { steel } \\
>55 \mathrm{HRC}\end{array}$} & \multirow{2}{*}{$\begin{array}{c}55-(68) \\
\text { HRC }\end{array}$} & \multirow{2}{*}{$\begin{array}{l}\text { X210Cr12/D3; X100CrMoV5/ A2; 81MoCrV42-16/ 613; } \\
\text { X153CrMoV12/ D2; 45NiCrMo16/-; 90MnCrV8/ O2. }\end{array}$} \\
\hline & & $\mathrm{H} 4.2$ & & & \\
\hline
\end{tabular}

offset from half the width of the part to be machined when it is smaller than the cutter diameter (to avoid intermittent machining when the cutter exits the machining process) and the cutter should be kept constant in the machining process. On numerically controlled milling systems it is preferable that machining is carried out in the direction of the feed of the milling tool.

There are a variety of studies (Denkena et al., 2015; Dombovari and Stépán, 2015; Pimenov et al., 2019) that analyse the forces involved in machining processes. High material hardness, incorrectly selected cutting parameters or tool geometry led to high values of cutting forces (Käsemodel et al., 2020).

It is characteristic for milling machining that the cutting forces change position during the process. Thus, it is important to consider two coordinate systems for its distribution: a fixed system $\left(\mathrm{F}_{\mathrm{x}}, \mathrm{F}_{\mathrm{y}}\right.$ and $F_{z}$ ), as in Figure 3, and the variable coordinate system $\left(F_{t}, F_{r}\right.$ and $\left.F_{a}\right)$. These last forces are called tangential force, radial force and axial force and are shown in Figure 4.

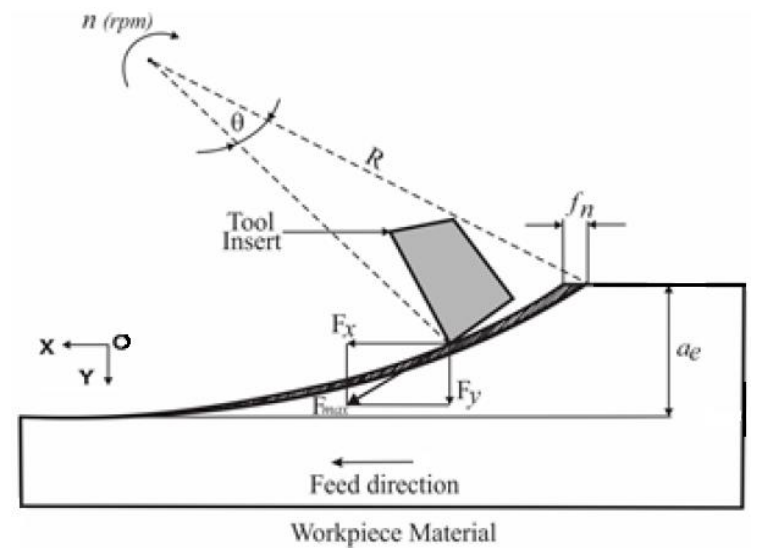

Fig. 3. Components of cutting forces in the cutting-edge area (Shnfir et al., 2019)
Equations (1) - (3) define the magnitudes of the above-mentioned forces (Lakić et al., 2014):

$$
\begin{gathered}
F_{t}=F_{x} \cos \varphi+F_{y} \sin \varphi[N] \\
F_{r}=F_{x} \sin \varphi-F_{y} \cos \varphi[N] \\
F_{a}=-F_{z}[N]
\end{gathered}
$$

Complex surface milling processes refer to those processes in which the milling tool is machining with both the face side, such as face milling, and the cylindrical side of the milling tool. This generates a minimum of two plan-frontal surfaces simultaneously, possibly functional. From the multitude of milling processes, as a result of which complex surfaces can be produced, a number of kinematic possibilities can be distinguished, as follows (Koromat, 2010):

1. Complex milling processes of contour surfaces.

2. Complex milling processes of slot surfaces.
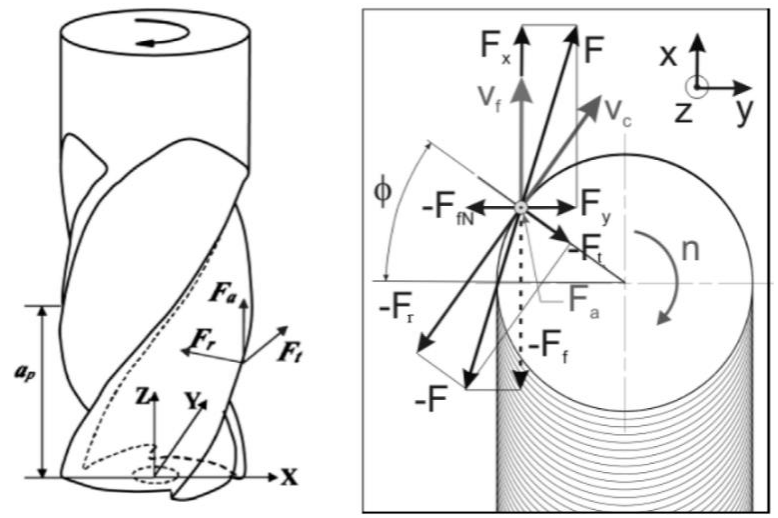

Fig. 4. Components of cutting forces when machining flat surfaces (Burek et al., 2019; Wang et al., 2014) 
Three functional surfaces are obtained by these machining processes.

3. Dedicated milling processes for complex surfaces. Among these, Figure 5 shows:

I. Linear ramp feed milling process;

II. The process of milling the slots inside the workpiece. It is carried out with axial plunge feed speeds and radial feed speeds;

III, IV and V. Milling process with circular kinematics in internal or external ramp;

VI, VII and X. Milling process with predefined paths for pocket machining;

VIII. Milling process with troncoidal kinematics. It is a kinematic often used for machining hard metal blanks, due to the constant tool engagement in the milling process;

IX. Plunge milling. The way the forces are positioned is different, having an axial layout instead of a tangential-radial layout, similar to drilling processes.
Due to the high cutting speeds, which produce high resultant forces, it is imperative that the orientationfixture devices of the tools have a maximum radial runout of $0.01 \mathrm{~mm}$ in order to achieve the longest possible tool life, which is a key requirement for milling hard metals. In HM and HSM machining, hydraulic or shrink fit holders, as well as mechanohydraulic holders, are mainly used.

The main disadvantage in machining hard metals by milling processes is that the tools wear out quite quickly, leading to low surface quality and less favourable machinability. This aspect can be fairly well controlled by the appropriate choice, depending on the blank material, the cutting tool material and a suitable geometry, the toolholder that has the capacity to meet the stresses generated in machining, as well as the selection of optimal technological parameters.

From a geometrical point of view, milling tools used for hard metal machining need to have a maximum
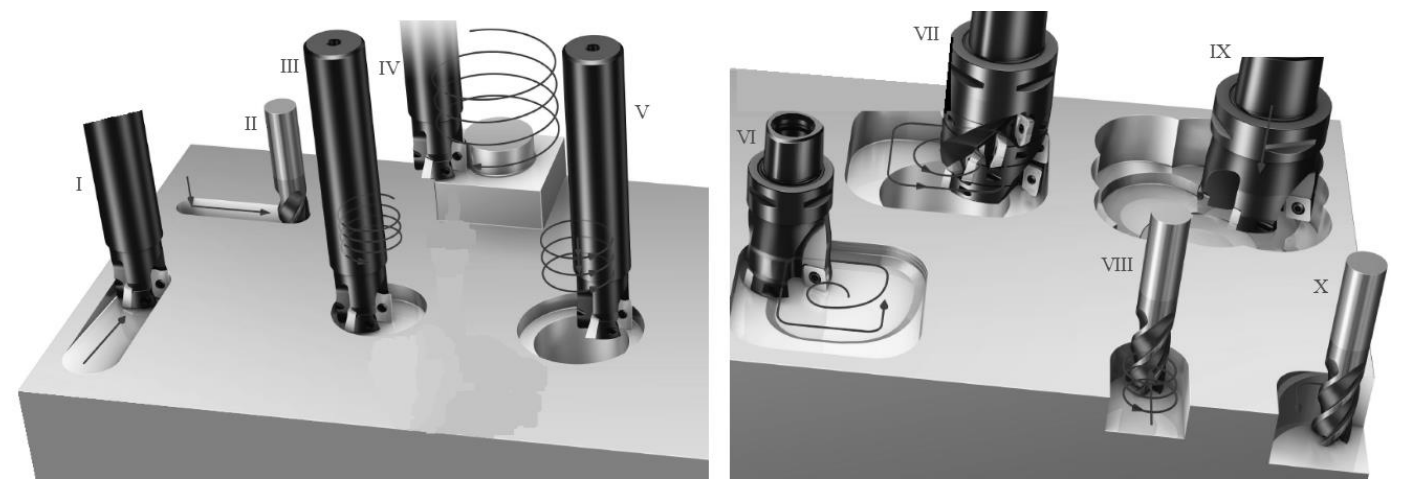

Fig. 5. Dedicated milling processes for complex or circular surfaces (Koromat, 2010)

\subsection{Technological systems}

The machines-tools used in hard metal milling must have specific characteristics to meet the processing conditions. Thus, the machines must have increased rigidity, especially for milling operations with high depth of cut, in the case of rough machining. This is why machines with high stability are used, with a vibration resistant cast iron frame. Milling technology systems must be able to move on at least three axes, with $3+2$ or 5 -axis machines being preferable, due to the complexity of the moulds or dies from which the hard materials are made. Polyarticulated robots can also be used, with obvious machining flexibility, but these are more suitable for finishing or semi-finishing machining. Similarly, other polyarticulated systems are favourable for these types of machining, such as hexapod machine-tools with high flexibility and rigidity. For all these types of machines it is mandatory to use $\mathrm{CNC}$ systems, due to the kinematic complexity required to produce complex surfaces.

In hard machining (HM), tools are subjected to buckling, bending and torsional stresses, unlike turning where only bending stresses occur. For these, toolholders that withstand such stresses must be used. number of teeth to facilitate chip formation and reduce machining temperatures. In the paper (Shnfir et al., 2019) experiments are carried out using ceramic inserts with different cutting-edge geometries for face milling of $\mathrm{C} 45$ blanks with a hardness of 48 HRC. It is found that the presence of radius on the cutting edges have a more favourable impact in terms of machinability than other types of defined geometries, as in Figure 6.

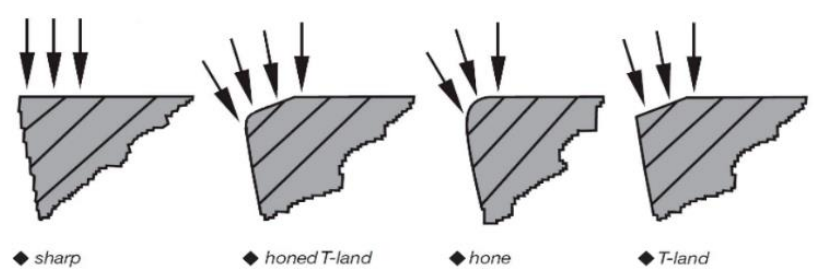

Fig. 6. Micro-geometries of cutting edges (Shnfir et al., 2019)

In particular, carbide tools with various coatings are used in the research, as shown in Table 2. Ceramic tools are also used, which only have to be applied under certain machining conditions, as well as boron cubic nitride (CBN) milling tools (Smith, 2008). 


\section{CUTTING PARAMETERS AND PROCESS PARAMETERS AND CHARACTERISTICS OF THE CHIPS GENERATED}

4.1 Cutting parameters and process parameters A summary of the machining characteristics (blank material and material hardness; tool material, removable insert and solid milling tools coatings; type of machining process), the technological parameters used (cutting speed and rpm; feed per tooth and feed speed; cutting depth and width) and some process parameters (maximum force and temperature values), based on a literature review, is presented in Table 2.

Table 2. Examples of the parameters used in milling hardened steels studies

\begin{tabular}{|c|c|c|c|c|c|c|c|c|c|c|c|}
\hline & \multicolumn{3}{|c|}{ Machining characteristics } & \multicolumn{6}{|c|}{ Technological parameters } & \multicolumn{2}{|c|}{ Process parameters } \\
\hline Source & $\begin{array}{l}\text { Workpiece } \\
\text { material }\end{array}$ & Tool type & $\begin{array}{c}\text { Machining } \\
\text { process }\end{array}$ & $\begin{array}{c}\mathrm{vc} \\
{[\mathrm{m} /} \\
\mathrm{min}]\end{array}$ & $\left.\begin{array}{c}\mathbf{n} \\
{[\mathbf{r p m}}\end{array}\right]$ & $\left.\begin{array}{c}\mathbf{v f} \\
{[\mathbf{m m} /} \\
\mathbf{m i n}]\end{array}\right]$ & $\begin{array}{c}\mathbf{f}_{\mathbf{z}} \\
{[\mathrm{mm} /} \\
\text { tooth }]\end{array}$ & {$\left[\begin{array}{c}\mathbf{a p}_{\mathbf{p}} \\
{[\mathbf{m m}]}\end{array}\right.$} & $\left.\mid \begin{array}{c}\mathbf{a}_{\mathrm{e}} \\
{[\mathrm{mm}]}\end{array}\right]$ & $\begin{array}{l}\text { Maximum } \\
\text { force }[N]\end{array}$ & $\begin{array}{c}\text { Maximum } \\
\text { temperature } \\
{\left[{ }^{\circ} \mathrm{C}\right]}\end{array}$ \\
\hline \multirow{2}{*}{$\begin{array}{l}\text { (Shnfir et } \\
\text { al., 2019) }\end{array}$} & \multirow{2}{*}{$\begin{array}{c}\text { C45U/ } 1045 \\
(48 \text { HRC) }\end{array}$} & \multirow{2}{*}{$\begin{array}{c}\text { Ceramic } \\
\mathrm{Al}_{2} \mathrm{O}_{3}+ \\
\mathrm{SiCW} \\
(\varnothing 40 ; \mathrm{z}=4) \\
\end{array}$} & \multirow{2}{*}{$\begin{array}{l}\text { Face } \\
\text { milling }\end{array}$} & 400 & 3200 & 2176 & 0.17 & \multirow{2}{*}{2} & \multirow{2}{*}{25.4} & 720 & \multirow{2}{*}{ - } \\
\hline & & & & 500 & 4000 & 1440 & 0.05 & & & 220 & \\
\hline \multirow{2}{*}{$\begin{array}{l}\text { (Shnfir et } \\
\text { al., 2019) }\end{array}$} & \multirow{2}{*}{$\begin{array}{l}\text { C45U / } 1045 \\
(53 \text { HRC })\end{array}$} & \multirow{2}{*}{$\begin{array}{c}\text { Ceramic } \\
\mathrm{Al}_{2} \mathrm{O}_{3}+ \\
\mathrm{SiCW} \\
(\varnothing 40 ; \mathrm{z}=4)\end{array}$} & \multirow{2}{*}{$\begin{array}{l}\text { Face } \\
\text { milling }\end{array}$} & 400 & 3200 & 2176 & 0.17 & \multirow{2}{*}{2} & \multirow{2}{*}{25.4} & 740 & \multirow{2}{*}{ - } \\
\hline & & & & 500 & 4000 & 1440 & 0.05 & & & 235 & \\
\hline \multirow{6}{*}{$\begin{array}{l}\text { (X. B. Cui } \\
\text { et al., 2015) }\end{array}$} & \multirow{6}{*}{$\begin{array}{c}\text { X40CrMoV5-1/ } \\
\text { H13 } \\
(48 \mathrm{HRC})\end{array}$} & \multirow{6}{*}{$\begin{array}{c}\text { Cemented } \\
\text { carbide } \\
\text { Ti }(\mathrm{C}, \mathrm{N})- \\
\mathrm{Al}_{2} \mathrm{O}_{3} \\
(\varnothing 125 ; \mathrm{z}=8)\end{array}$} & \multirow{6}{*}{$\begin{array}{l}\text { Face } \\
\text { milling }\end{array}$} & 200 & 510 & 164 & \multirow{6}{*}{0.04} & \multirow{6}{*}{0.2} & \multirow{6}{*}{75} & 85 & \\
\hline & & & & 1000 & 2550 & 816 & & & & 155 & \\
\hline & & & & 1400 & 3600 & 1152 & & & & 115 & - \\
\hline & & & & 1800 & 4600 & 1472 & & & & 120 & \\
\hline & & & & 2000 & 5100 & 1632 & & & & 125 & \\
\hline & & & & 2400 & 6120 & 1960 & & & & 135 & \\
\hline & X40CrMoV5-1/ & & & & & & & & 15 & & 820 \\
\hline (X. Cu1 et & $\mathrm{H} 13$ & $\begin{array}{c}\text { CBN } \\
(\alpha 125 \cdot 7-8)\end{array}$ & $\begin{array}{l}\text { Face } \\
\text { milling }\end{array}$ & 1200 & 3060 & 1960 & 0.08 & 0.2 & 45 & 63 & 930 \\
\hline & & & & & & & & & 75 & & 1010 \\
\hline & & & & 400 & 1020 & 490 & & & & 180 & \\
\hline & & Cemented & & 1200 & 3060 & 1470 & & & 10 & 155 & \\
\hline (Cui and & $\underset{\mathrm{X} 40 \mathrm{CrMoV} 5-1 /}{4}$ & carbide & Face & 2400 & 6115 & 2940 & & & & 140 & \\
\hline & $\begin{array}{c}H 13 \\
(47 \mathrm{HRC})\end{array}$ & $\mathrm{T} 1(\mathrm{C}, \mathrm{N})-$ & milling & 400 & 1020 & 490 & 0.06 & 0.4 & & 155 & - \\
\hline & & $\begin{array}{c}\mathrm{Al}_{2} \mathrm{U}_{3} \\
(\varnothing 125 ; \mathrm{z}=8)\end{array}$ & & 1200 & 3060 & 1470 & & & 25 & 125 & \\
\hline & & & & 2400 & 6115 & 2940 & & & & 120 & \\
\hline & & & & 150 & 2400 & 2400 & 0.15 & 0.1 & 20 & 225 & 700 \\
\hline & & & & \begin{tabular}{|l|}
150 \\
\end{tabular} & 2400 & 2400 & 0.15 & 0.2 & 20 & 75 & 590 \\
\hline $\begin{array}{c}\text { (Riza and } \\
\text { Adesta }\end{array}$ & X40CrMoV5-1/ & CBN & Pocket & 200 & 3200 & 1280 & 0.1 & 0.15 & 20 & 215 & 720 \\
\hline $\begin{array}{l}\text { Adesta, } \\
2016)\end{array}$ & $\begin{array}{c}H 13 \\
(48 \mathrm{HRC})\end{array}$ & $(\varnothing 20 ; z=4)$ & milling & 250 & 4000 & 480 & 0.05 & 0.1 & 20 & 160 & 120 \\
\hline & & & & \begin{tabular}{|l|}
250 \\
\end{tabular} & 4000 & \begin{tabular}{|l|}
480 \\
\end{tabular} & 0.05 & 0.2 & 20 & 85 & 140 \\
\hline & & & & 250 & 4000 & 2400 & 0.15 & 0.1 & 20 & 70 & 100 \\
\hline (Ravi and & 40CrMnMo7/ & Uncoated & & 75 & 1500 & 60 & & & & 260 & 240 \\
\hline Gurusamy, & $P 20$ & carbide & Contour & 100 & 2000 & 90 & 0.02 & 0.5 & 10 & 235 & 360 \\
\hline 2020) & (48 HRC) & $(\varnothing 16 ; z=2)$ & & 125 & 2500 & 100 & & & & 220 & 370 \\
\hline & & & & 250 & 4000 & 2400 & & & & 1624.5 & 839.7 (sim.) \\
\hline & & carbide & & \begin{tabular}{|l|}
300 \\
\end{tabular} & 5000 & 3000 & 0.2 & & & 1239.5 & 984.5 (sim.) \\
\hline Wang, et & $\mathrm{H} 13$ & $\mathrm{Ti}(\mathrm{N}, \mathrm{C})-$ & $\begin{array}{l}\text { Contour } \\
\text { milling }\end{array}$ & 350 & 5600 & 3360 & & 2 & 2 & 1157.8 & 1080 (sim.) \\
\hline al., 2019) & (50 HRC) & $\mathrm{Al}_{2} \mathrm{O}_{3}$ & & 300 & 5000 & 2250 & 0.15 & & & 1140.3 & 873.2 (sim.) \\
\hline & & $(\varnothing 20 ; z=3)$ & & 300 & 5000 & 3750 & 0.25 & & & 1372.5 & 1152 (sim.) \\
\hline & & Cemented & & 200 & 3200 & 1280 & & & & & 395 \\
\hline (Zhang et & X40CrMoV5-1/ & carbide & Contour & 300 & 4800 & 1920 & & & & & 480 \\
\hline al., 2019) & (50 HRC) & $\begin{array}{c}\mathrm{Ti}(\mathrm{C}, \mathrm{N})- \\
\mathrm{Al}_{2} \mathrm{O}_{3} \\
(\varnothing 20 ; \mathrm{z}=2)\end{array}$ & milling & 400 & 6400 & 2560 & 0.2 & 2 & 2 & - & 520 \\
\hline
\end{tabular}

$* \mathrm{v}_{\mathrm{c}}=$ cutting speed; $\mathrm{v}_{\mathrm{f}}=$ feed speed; $\mathrm{f}_{\mathrm{z}}=$ feed per tooth; $\mathrm{a}_{\mathrm{p}}=$ axial depth of cut; $\mathrm{a}_{\mathrm{e}}=$ radial depth of cut. 


\subsection{Characteristics of the chips generated}

In order to obtain technological surfaces, it is necessary to remove a volume of material, and this process is carried out in the form of chips, as a result of predominantly shearing phenomena. In hard steel machining, the chips are continuous and have a structure of adiabatic shear bands (ASB). The adiabatic aspect refers to the fact that it is a process that occurs faster than the heat exchange takes place and therefore oxidation occurs in the chips rather than phase transformation when the technological parameters are optimised. Of course, chip morphology also depends on the mechanical, thermal and thermo-mechanical properties of the metal to be machined.

The appearance of a chip observed by electron microscopy is shown in Figure 7, obtained by face milling under the following conditions: cutting speed $200 \mathrm{~m} / \mathrm{min}$, feed speed $600 \mathrm{~mm} / \mathrm{min}$, cutting width $31.5 \mathrm{~mm}$ and cutting depth $0.3 \mathrm{~mm}$, using a $63 \mathrm{~mm}$ diameter milling cutter with 6 removable CBN inserts. Chips formed in adiabatic shear bands were obtained, and the pitch size of the shear bands is approximately $100 \mu \mathrm{m}$ (Cui et al., 2013).

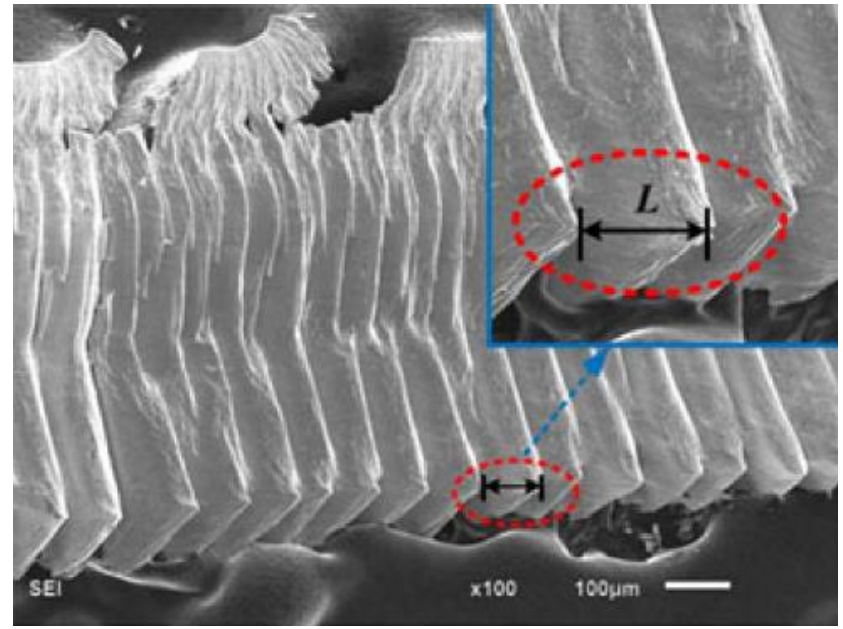

Fig. 7. Pitch size at chip formation in adiabatic shear bands (Cui et al., 2013)

Large chip lengths are obtained when milling an X40CrMoV5-1 (H13) blank with hardness of 47 HRC with carbide inserts when cutting speeds are low and the chip width is large, while very small chip lengths are obtained at high cutting speeds (Cui and Zhao, 2015).

When machining X40CrMoV5-1 (AISI H13) blanks with a hardness of $50 \mathrm{HRC}$ at a speed of $250 \mathrm{~m} / \mathrm{min}$ and a feed per tooth of $0.2 \mathrm{~mm} /$ tooth at a depth and cutting width of $2 \mathrm{~mm}$, oxidation effects are found to be observed: blue, black and red colours are associated with $\mathrm{FeO}, \mathrm{Fe}_{3} \mathrm{O}_{4}$ and $\mathrm{Fe}_{2} \mathrm{O}_{3}$ compounds ( $\mathrm{Li}$ et al., 2019).

Figure 8 shows the evolution of microhardness between points 1-5 in zones $A$ and $B$ in a section of a chip obtained when machining an X40CrMoV5-1 (H13) blank with a hardness of $50 \mathrm{HRC}$ (Li, Zhang, Yan, and Zhang, 2018). In area A, there is a tendency for the microhardness to increase towards point 3 due to the compression of the chip in that area, while in area $\mathrm{B}$ the microhardness tends to increase towards point 5. This is due to the formation of a hard white layer (WL), which is caused by the appearance of austenite phases.

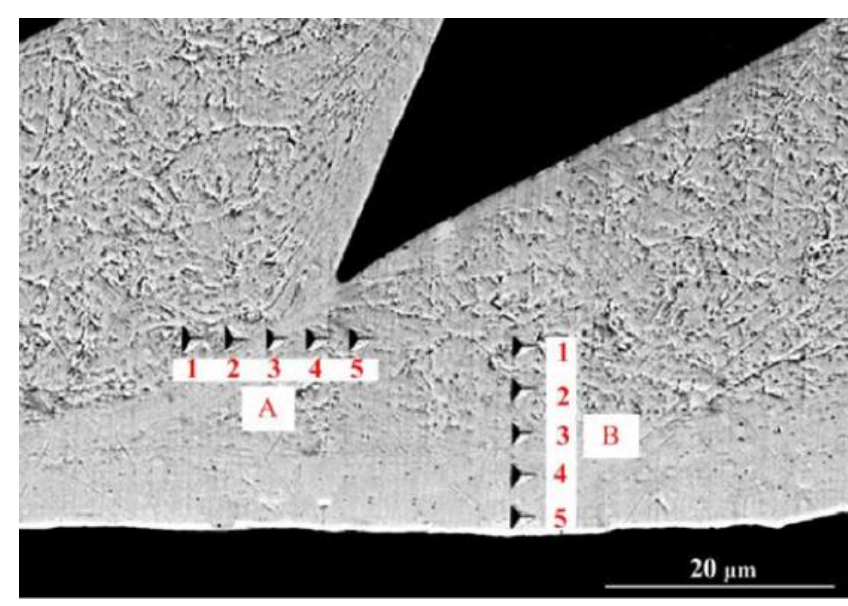

Fig. 8. Microhardness measurement points on chip formed in adiabatic shear bands (Li, Zhang, Yan, and Zhang, 2018)

\section{TOOL WEAR AND TOOL LIFE}

Tool wear is caused by deformation or damage to the edges of the cutting tool during machining due to interactions between the tool and the workpiece. The durability of the cutting tool directly affects the cost of machining and is an important issue in production process efficiency studies.

Most of the research in the field of hard machining focuses on improving tool life. This can be defined as the volume of material removed or the time the tool has been engaged in cutting the material before it achieves certain catastrophic or crater wear criteria. The tool can no longer be used once such destructive wear has formed.

In the study presented by (Shnfir et al., 2019) it is shown that fine cutting tool wear is obtained when machining at lower feed speeds up to $1000 \mathrm{~mm} / \mathrm{min}$ for machining a $\mathrm{C} 45 \mathrm{U}$ blank with a hardness of 53 HRC. For feed speeds higher than $1000 \mathrm{~mm} / \mathrm{min}$, correlated with cutting speeds, more significant wear is obtained, reaching crater-type wear sizes.

A steady evolution of $\mathrm{Ti}(\mathrm{N}, \mathrm{C})$ and $\mathrm{Al}_{2} \mathrm{O}_{3}$ coated carbide tool wear when machining an X40CrMoV5-1 (H13) blank is observed in Figure 9. Up to a removed material volume of about $8500 \mathrm{~mm}^{3}$ by chips formation, wear values up to $105 \mu \mathrm{m}$ are observed, hence the appearance of fine chipping on the cutting edges. Exceeding this value of the volume of material removed, a sudden evolution of the curve is observed, with the presence of critical crater cracks with values 
of $204.3 \mu \mathrm{m}$. The durability of the tool is thus determined by the volume of material removed until destructive wear occurs (Li, Zhang, and Zhang, 2018).

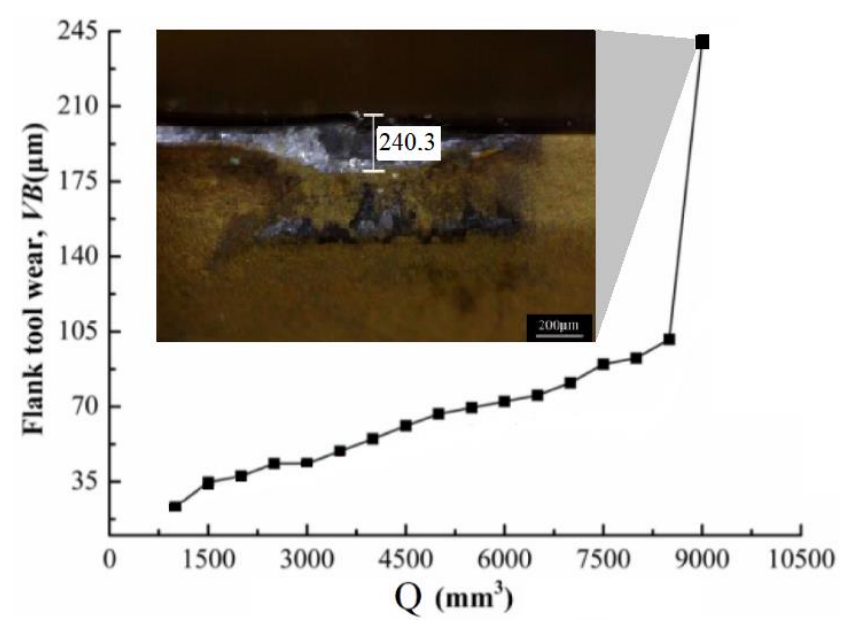

Fig. 9. Tool wear evolution as a function of the removed material volume Q (Li, Zhang, and Zhang, 2018)

When machining an X40CrMoV5-1 (H13) blank with a hardness of $47 \mathrm{HRC}$ in face milling, it is found that increased tool durability is obtained when the cutting speed is low, around $400 \mathrm{~m} / \mathrm{min}$, with large cutting widths. When cutting speeds are relatively high, around $2400 \mathrm{~m} / \mathrm{min}$, tool durability is found to be increased only for smaller chip widths. Moreover, it is found that adhesion wear is present on the cutting edges with increasing cutting speeds (Cui and Zhao, 2015).

\section{SURFACE INTEGRITY}

Surface integrity refers to the condition and properties of a surface resulting from machining or any other operation and the relationships they form in functionality. There are two main aspects that describe the characteristics of surface integrity. The first is related to surface quality or surface topography and the second refers to characteristics of the machined substrate such as microstructure, mechanical properties and residual stresses (Davim, 2010).

The most commonly used parameter for characterizing surface quality is the arithmetic average roughness, $\mathrm{Ra}$, expressed in $\mu \mathrm{m}$ (Liao et al., 2021). Figure 10 shows most of the characteristics of the layers that form on the machined surface. Thus, $\mathbf{g}$ represents the thickness of the surface layer, $\mathbf{s}$ represents the overall structure of the surface layer, $\mathbf{u}$ is the thermally influenced area with changes in hardness, $\boldsymbol{\sigma}$ represents the residual stresses throughout the surface layer structure, $\mathbf{S}_{\mathbf{f}}$ are defects occurring in the surface layers. Defects that can occur are: 1 - microcracks, 2 - macrocracks, 3 microcondensation of the base material, 4 porosities, 5 - voids, 6 - inclusions (Grzesik, 2017).

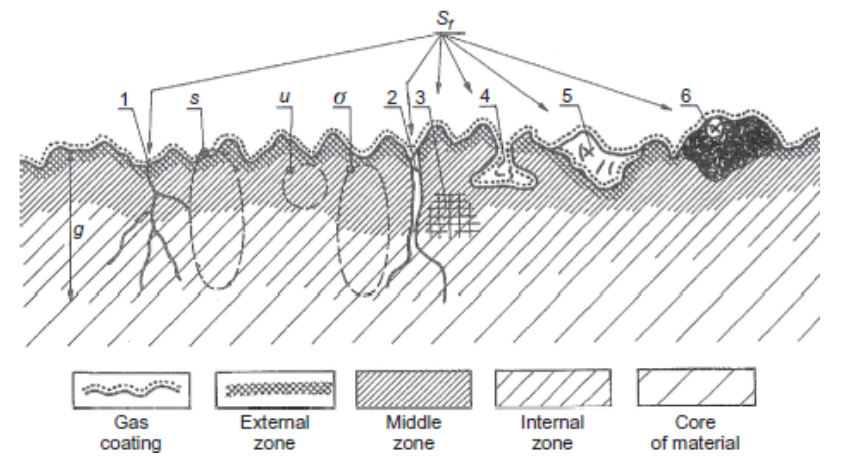

Fig. 10. Factors that characterise the surface machined layers (Grzesik, 2017)

In the following, some aspects related to the geometrical and macrostructural characteristics of the surfaces, as well as the microstructural and physicalmechanical characteristics of the substrates are detailed. Other relevant aspects of studies identified in the literature are summarised in Table 3.

\subsection{Geometrical features and macrostructural characteristics}

Elements of surface texture related to geometrical and macrostructural aspects are mainly characterised by the roughness of the generated surfaces. The quality of surfaces plays a defining role in the performance and functioning of the component parts of an assembly.

In the study conducted by (Cui et al., 2015) when machining an X40CrMoV5-1 (H13) blank with a hardness of $47 \mathrm{HRC}$, it is shown that with increasing chipping speeds, the average roughness values increase from values not exceeding $0.1 \mu \mathrm{m}$ to values of $0.4 \mu \mathrm{m}$, Figure 11. For all cutting speeds studied, processes were carried out at the same feed speed of $0.04 \mathrm{~mm} /$ tooth.

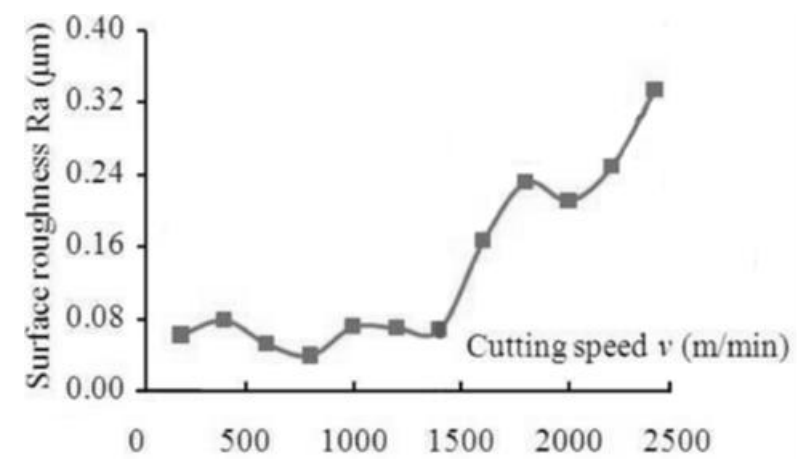

Fig. 11. Roughness evolution as a function of cutting speed when face machining of $\mathrm{H} 13$ workpieces with hardness of 47 HRC (Cui et al., 2015)

When machining 36CrNiMo4 (AISI 4340) blanks and 45 HRC hardness with a TiAlN coated tungsten carbide end mill (Hassanpour et al., 2016), milling machining with a feed per tooth of $0.04 \mathrm{~mm} /$ tooth and cutting speeds of $50 \mathrm{~m} / \mathrm{min}$ and $150 \mathrm{~m} / \mathrm{min}$, was performed. It was found that for higher cutting speeds the roughness obtained, so the depths and peaks of the 
traces left by the tool teeth on the milled surface, as well as other defects, are less pronounced compared to milling operations with lower cutting speeds.

\subsection{Microstructural characteristics of surface layers}

After machining hardened steels with hardnesses exceeding 45 HRC, hard white layers often appear near the machined surfaces, for several reasons: the interaction of the heated surfaces with atmosphere elements and from the removable inserts coatings, thus forming oxides, nitrides or other compounds; grain refining due to thermo-plastic deformations at the surfaces; and the development of phase transformations, which are also the main cause of the increase in hardness of the surface layers.

In the study presented by (Čilliková et al, 2021), face milling of a 61 HRC blank from a material 110Cr6, used for bearings is carried out using the technological parameters given in Table 3. Metallographic analysis revealed a thin hard white layer (WL) influenced by tool wear, as well as heataffected zone (HAZ) that appear microscopically darkened, disposed below the white layer. The hard white layer is due to the increase in temperature during processing, which reaches the austenitizing zone, leading to hardening of the surface layer, while the darkened heat affected zones show a decrease in

Table 3. Examples of some machinability characteristics in milling processes in hardened steel machining studies

\begin{tabular}{|c|c|c|c|c|c|c|c|c|c|c|}
\hline \multirow[b]{2}{*}{ Source } & \multicolumn{2}{|c|}{ Machining characteristics } & \multicolumn{4}{|c|}{ Technological parameters } & \multicolumn{4}{|c|}{ Machinability characteristics } \\
\hline & $\begin{array}{c}\text { Workpiece } \\
\text { material }\end{array}$ & Tool type & $\begin{array}{c}\mathbf{v c} \\
{[\mathbf{m} /} \\
\mathrm{min}]\end{array}$ & $\begin{array}{c}\mathbf{v f} \\
{[\mathbf{m m} /} \\
\mathrm{min}]\end{array}$ & $\begin{array}{c}\mathbf{a p}_{\mathbf{p}} \\
{[\mathrm{mm}]}\end{array}$ & $\begin{array}{c}\mathbf{a e} \\
{[\mathrm{mm}]}\end{array}$ & $\begin{array}{c}\text { VB } \\
{[\mathrm{mm}]}\end{array}$ & $\begin{array}{c}\mathbf{R a} \\
{[\mu \mathrm{m}]}\end{array}$ & $\begin{array}{c}\sigma_{\mathrm{RS}} \\
{[\mathrm{MPa}]}\end{array}$ & $\begin{array}{c}\mathbf{Q} \\
{\left[\mathbf{c m}^{3} /\right.} \\
\mathbf{m i n}]\end{array}$ \\
\hline $\begin{array}{l}\text { (Čilliková et } \\
\text { al., 2021) }\end{array}$ & $\begin{array}{l}\text { 100Cr6 } \\
\text { (61 HRC) }\end{array}$ & $\begin{array}{c}\text { Cemented } \\
\text { carbide } \\
\mathrm{Ti}(\mathrm{N}, \mathrm{C})+\mathrm{TiN} \\
(\emptyset 50 ; \mathrm{z}=2)\end{array}$ & 78.5 & 112 & 0.25 & 30 & 0.05 & - & - & 4.2 \\
\hline \multirow{5}{*}{$\begin{array}{l}\text { (Stupakov et } \\
\text { al., 2016) }\end{array}$} & \multirow{5}{*}{$\begin{array}{c}\text { 100Cr6 } \\
(50 \mathrm{HRC})\end{array}$} & \multirow{5}{*}{$\begin{array}{c}\text { Cemented } \\
\text { carbide } \\
\mathrm{Ti}(\mathrm{N}, \mathrm{C})+\mathrm{TiN} \\
(\emptyset 50 ; \mathrm{z}=2)\end{array}$} & \multirow{5}{*}{78} & \multirow{5}{*}{112} & \multirow{5}{*}{0.25} & \multirow{5}{*}{40} & 0.05 & \multirow{5}{*}{ - } & 100 & \multirow{5}{*}{ - } \\
\hline & & & & & & & 0.2 & & 330 & \\
\hline & & & & & & & 0.4 & & 410 & \\
\hline & & & & & & & 0.6 & & 440 & \\
\hline & & & & & & & 0.8 & & 380 & \\
\hline \multirow{5}{*}{$\begin{array}{l}\text { (Neslušan et } \\
\text { al., 2019) }\end{array}$} & \multirow{5}{*}{$\begin{array}{c}\text { 100Cr6 } \\
(61 \mathrm{HRC})\end{array}$} & \multirow{5}{*}{$\begin{array}{c}\text { Cemented } \\
\text { carbide Ti (N, } \\
\text { C) +TiN } \\
(\varnothing 50 ; \mathrm{z}=2)\end{array}$} & \multirow{5}{*}{78.5} & \multirow{5}{*}{110} & \multirow{5}{*}{0.25} & \multirow{5}{*}{30} & 0.05 & \multirow{5}{*}{-} & 470 & \\
\hline & & & & & & & 0.2 & & 850 & \\
\hline & & & & & & & 0.4 & & 320 & - \\
\hline & & & & & & & 0.6 & & 540 & \\
\hline & & & & & & & 0.8 & & 420 & \\
\hline \multirow{2}{*}{$\begin{array}{c}\text { (Shnfir et al., } \\
\text { 2019) }\end{array}$} & \multirow{2}{*}{$\begin{array}{c}\text { C45U/ } 1045 \\
(48 \text { HRC })\end{array}$} & \multirow{2}{*}{$\begin{array}{c}\text { Ceramic } \\
\mathrm{Al}_{2} \mathrm{O}_{3}+\mathrm{SiCW} \\
(\emptyset 40 ; \mathrm{z}=4) \\
\end{array}$} & 300 & 1250 & \multirow[b]{2}{*}{2} & \multirow[b]{2}{*}{25.4} & 0.056 & \multirow[b]{2}{*}{-} & & \\
\hline & & & 500 & 2720 & & & 0.023 & & - & - \\
\hline (Shnfir et al.. & $\mathbf{C 4 5 U} / 1045$ & Ceramic & 300 & 1250 & & & 0.06 & & & \\
\hline 2019) & $(53 \mathrm{HRC})$ & $\begin{array}{c}\mathrm{Al}_{2} \mathrm{O}_{3}+\mathrm{SiCW} \\
(\varnothing 40 ; \mathrm{z}=4)\end{array}$ & 500 & 2720 & 2 & 25.4 & 0.025 & - & - & - \\
\hline & & & 200 & 164 & & & 0.02 & 0.07 & & \\
\hline & & Cemented & 800 & 656 & & & 0.038 & 0.06 & & \\
\hline (Cu1 et al., & $\mathbf{1} / H 13$ & $T:(C)$ & 1400 & 1152 & 0.2 & 75 & 0.041 & 0.08 & - & - \\
\hline & & $\begin{array}{l}11(\mathrm{C}, \mathrm{N})-\mathrm{Al}_{2} \mathrm{O}_{3} \\
(\varnothing 125 \cdot 7=8)\end{array}$ & 1800 & 1472 & & & 0.06 & 0.24 & & \\
\hline & & & 2000 & 1632 & & & 0.075 & 0.2 & & \\
\hline & & & 2400 & 1960 & & & 0.1 & 0.33 & & \\
\hline & & & 113 & 2750 & & & & & & 20.67 \\
\hline (Viswanathan & 40C CPMnivo & $\mathrm{CBN}$ & 126 & 2500 & 0.22 & 10 & & & & 19.66 \\
\hline et al., 2021) & (34 HRC) & $(\varnothing 10)$ & 138 & 2250 & & 10 & - & - & - & 16.88 \\
\hline & & & 150 & 2750 & 0.2 & & & & & 19.5 \\
\hline (Ravi and & 40CrMnMo7/ & Uncoated & 75 & 60 & & & & 3 & & \\
\hline Gurusamy, & $P 20$ & carbide & 100 & 80 & 0.5 & 10 & - & 2.5 & - & - \\
\hline 2020) & (48 HRC) & $(\varnothing 16 ; z=2)$ & 125 & 100 & & & & 2.3 & & \\
\hline & & Cemented & & & & & 0.05 & & & 2.3 \\
\hline and Zhang, & 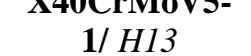 & carbide & 200 & 1280 & 2 & 2.5 & 0.075 & - & - & 6 \\
\hline 2018) & (50 HRC) & $\mathrm{Ti}(\mathrm{N}, \mathrm{C})-\mathrm{Al}_{2} \mathrm{O}_{3}$ & & & & & 0.1 & & - & 7.5 \\
\hline & & & & & & & 0.24 & & & 9 \\
\hline
\end{tabular}




\begin{tabular}{|c|c|c|c|c|c|c|c|c|c|c|}
\hline \multirow[b]{2}{*}{ Source } & \multicolumn{2}{|c|}{ Machining characteristics } & \multicolumn{4}{|c|}{ Technological parameters } & \multicolumn{4}{|c|}{ Machinability characteristics } \\
\hline & $\begin{array}{l}\text { Workpiece } \\
\text { material }\end{array}$ & Tool type & $\begin{array}{c}\mathbf{v}_{\mathbf{c}} \\
{[\mathbf{m} /} \\
\mathbf{m i n}]\end{array}$ & $\begin{array}{c}\mathbf{v f}_{\mathrm{f}} \\
{[\mathrm{mm} /} \\
\mathrm{min}]\end{array}$ & $\begin{array}{c}\mathbf{a}_{\mathbf{p}} \\
{[\mathbf{m m}]}\end{array}$ & $\begin{array}{c}\mathbf{a}_{\mathbf{e}} \\
{[\mathbf{m m}]}\end{array}$ & $\begin{array}{c}\text { VB } \\
{[\mathrm{mm}]}\end{array}$ & $\begin{array}{c}\mathbf{R a} \\
{[\mu \mathbf{m}]}\end{array}$ & $\begin{array}{c}\sigma_{\mathrm{RS}} \\
{[\mathrm{MPa}]}\end{array}$ & $\begin{array}{c}\mathbf{Q} \\
{\left[\mathrm{cm}^{3} /\right.} \\
\mathbf{m i n}]\end{array}$ \\
\hline \multirow{5}{*}{$\begin{array}{c}\text { (Li, Zhang, } \\
\text { Yan, et al., } \\
2018)\end{array}$} & \multirow{5}{*}{$\begin{array}{c}\text { X40CrMoV5- } \\
\mathbf{1} / \mathrm{H} 13 \\
(50 \mathrm{HRC})\end{array}$} & \multirow{5}{*}{$\begin{array}{c}\text { Cemented } \\
\text { carbide } \\
\mathrm{Ti}(\mathrm{N}, \mathrm{C})-\mathrm{Al}_{2} \mathrm{O}_{3} \\
(\emptyset 20 ; \mathrm{z}=2)\end{array}$} & \multirow{5}{*}{250} & \multirow{5}{*}{1600} & \multirow{5}{*}{2} & \multirow{5}{*}{2} & \multirow{5}{*}{ - } & 1.3 & 245 & \multirow{5}{*}{ - } \\
\hline & & & & & & & & 1.4 & 255 & \\
\hline & & & & & & & & 1.9 & 295 & \\
\hline & & & & & & & & 2 & 380 & \\
\hline & & & & & & & & 2.5 & 410 & \\
\hline
\end{tabular}

$* \mathrm{v}_{\mathrm{c}}=$ cutting speed; $\mathrm{v}_{\mathrm{f}}=$ feed speed; $\mathrm{a}_{\mathrm{p}}=$ axial depth of cut; $\mathrm{a}_{\mathrm{e}}=$ radial depth of cut; $\mathrm{VB}=$ tool wear; $\sigma_{\mathrm{RS}}=$ residual stresses; $\mathrm{Q}=$ volume of chips removed.

hardness (Neslušan et al., 2015). Martensite phases have significantly lower hardness values, which means that the white layer is predominantly formed by austenite phases (Neslušan et al., 2019).

Stupakov showed that (Stupakov et al., 2016) when machining with the parameters mentioned in Table 3, a 100Cr6 bearing steel having a hardness of $50 \mathrm{HRC}$, the optimal wear of changing removable inserts is when VB reaches a value close to $0.4 \mathrm{~mm}$. Visible differences in the hard white layer for a tool wear VB of $0.4 \mathrm{~mm}$ and $\mathrm{VB}$ of $0.8 \mathrm{~mm}$, respectively, are shown in Figure 12.

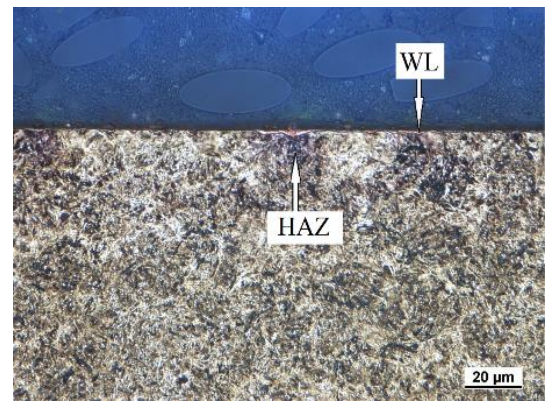

a)

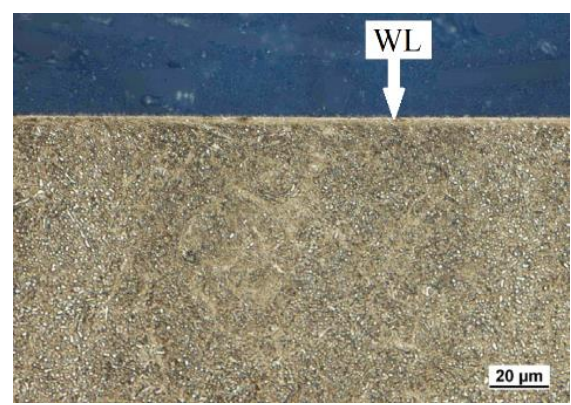

b) cutting tool have a significant influence on the presence of oxidation effects.

\subsection{Physico-mechanical characteristics of surface layers} A frequently used parameter for analysing the quality of surfaces and surface layers machined is the residual stresses. In milling processes these occur in the layers neighbouring the machined surface and are caused by the following phenomena:

- Mechanical Affected-Zone (MAZ);

- Heat Affected-Zone (HAZ);

- Phase transformations in the microstructure of the machined material.

Fig. 12. Metallographic analysis. a) White layer (WL) under which small darkened zones (HAZ) are located when machining 110Cr6 blanks with hardness of 61 HRC (Čilliková et al., 2021); White layer (WL) is observed when machining 110Cr6 blanks with hardness of $50 \mathrm{HRC}$ for: b) critical tool wear of $\mathrm{VB}=0.4 \mathrm{~mm}$ (Stupakov et al., 2016), respectively c) wear of $\mathrm{VB}=0.8 \mathrm{~mm}$ (Stupakov et al., 2016)

In the research (Hassanpour et al., 2016) a hard white layer thickness with austenite phases of about 14.5 $\mu \mathrm{m}$ was obtained when machining a blank of type 36CrNiMo4 (AISI 4340) and hardness of $45 \mathrm{HRC}$ at a cutting speed of $150 \mathrm{~m} / \mathrm{min}$ and feed per tooth of $0.04 \mathrm{~mm} /$ tooth.

Oxidation reactions are observed on the machined surface when iron interacts with oxygen ( $\mathrm{Li}$ et al., 2018) and, depending on the degree of oxidation, different colours appear on the machined surface. These correspond to oxidic compounds of $\mathrm{FeO}, \mathrm{Fe}_{3} \mathrm{O}_{4}$ and $\mathrm{Fe}_{2} \mathrm{O}_{3}$, with the association of light blue, black and red colours. It is found that the machining temperature and the machining exposure period of the

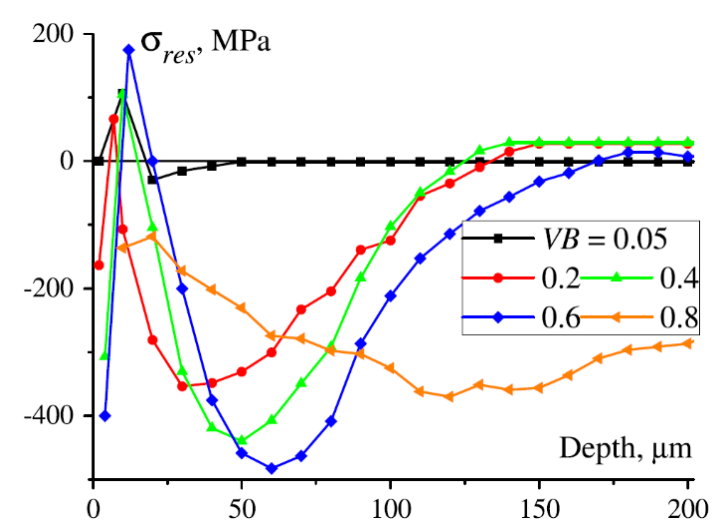

Fig. 13. Evolution of residual stresses in relation to wear of cutting inserts in face milling of $100 \mathrm{Cr} 6$ material with hardness of 50 HRC (Stupakov et al., 2016) 
In research conducted by (Stupakov et al., 2016) on face milling of a 100Cr6 blank with hardness of 50 HRC, the evolution of residual stresses in the substrates neighbouring the machined surface was analysed when using cutting inserts with different degrees of wear. The determination of residual stresses was carried out by the electrolytic erosion layer removal method for a $10 \mathrm{~mm}$ x $40 \mathrm{~mm}$ sample of the workpiece. A sinusoidal evolution of these stresses was shown in Figure 13, starting from compressive residual stresses near the machined surface, followed by a sharp decrease towards tensile values (positive - about $200 \mathrm{MPa}$ ), followed by an increase, up to compressive values of $-400 \mathrm{MPa}$, followed by their stability. This sinusoidal behaviour is more pronounced with increasing wear of the cutting inserts.

Another parameter to characterize the mechanical properties of the processed layer is the microhardness. For example, in the study (Li et al., 2018), the microhardness evolution of the surface layer was analyzed when machining an X40CrMoV51 (H13) blank with a hardness of 50 HRC by face milling. The microhardness was determined by nanoidentation at various points of an electroerosion cut sample, on three columns at $25 \mu \mathrm{m}$ spacing, as shown in Figure 14. The evolution of microhardness from the machined surface to a depth of $35 \mu \mathrm{m}$ was established and it was concluded that, due to plastic deformation at the interface between the tool and the workpiece, microhardness tends to have high values towards the machined surface.

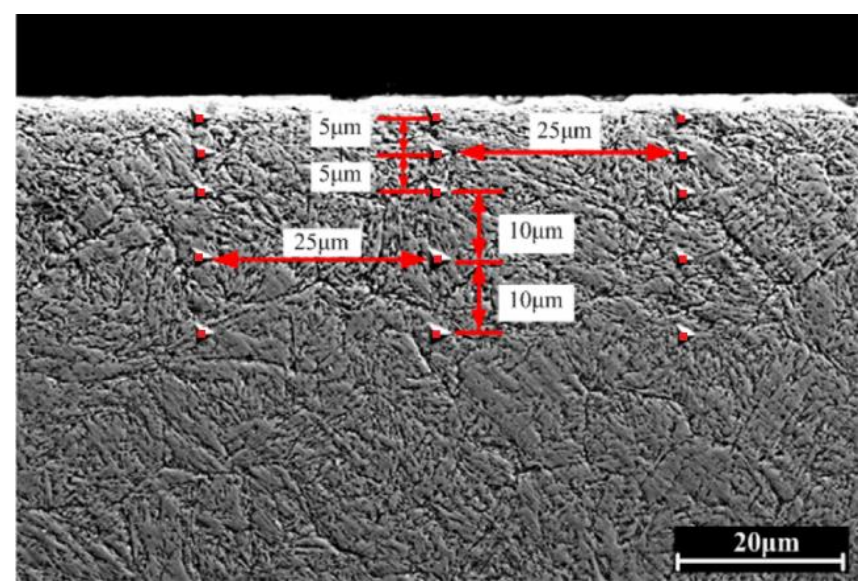

Fig. 14. Indentation points when measuring microhardness on the machined surface ( $\mathrm{Li}$ et al., 2018)

\section{CONCLUSIONS}

The main argument and advantage of machining hard metals by milling technologies is that after using a die or other parts with complex surfaces, they can be machined by this method. Thus, it is possible to return surfaces to their original shape without additional costs resulting from heat treatment and grinding operations.

The following conclusions have been summarized from the study carried out, in relation to the machinetools used for these processes, the forces and temperatures in the processes, chip formation and the integrity of the machined surfaces.

Machine-tools used for milling hard materials must have a very rigid configuration, especially for rough machining, due to the high forces involved in the technological system. Machine-tools are often made of large, heavy blocks of cast iron that absorb any vibrations during machining processes. The main spindle of the machine tool has to be very well centred due to machining at high cutting speeds and the tool orientation-fixing systems have to be of high precision to keep the tool axis coaxial with the main spindle axis.

Cutting forces can be reduced by increasing the cutting speed or decreasing the feed speed.

Temperatures in the cutting process are an important parameter for optimizing the milling process because of their influence on the durability of the cutting tool and the integrity of the surfaces.

The formation of chips in adibate shear bands is specific, in particular, to the machining of hard metal parts. This chip formation mechanism is due to thermoplastic instabilities, and cyclic cracks facilitate these breakage mechanisms by forming adiabatic shear bands. The pitch size of the shear bands formed in the milling process, for the case of chip formation in shear bands, progressively decreases with increasing cutting speed and feed speed.

The austenite phases present in the chip structure resulting from machining increase with rising cutting speed and feed speed, leading to a significant decrease in austenite phases on machined surfaces, thus reducing the hard white layers that normally form with wear on the cutting tool edges. The colour variations in the chips formed are due to oxidation, where blue, black and red colours correspond in order for $\mathrm{FeO}, \mathrm{Fe}_{3} \mathrm{O}_{4}$ and $\mathrm{Fe}_{2} \mathrm{O}_{3}$.

To achieve proper surface quality when milling hard metals, it is recommended that machining should be carried out at high cutting speeds but relatively low feed speeds. This will have an obvious benefit in levelling out the plastic deformations that are found on the machined surface.

Low roughness values on the machined surfaces are obtained by using low values of the rays on the cutting edges of the cutting tools. It is found that the tools used in hard metal machining should have as small rays as possible in the area of the cutting edges so that no hard white layers form on the machined surface. This condition is beneficial in order to avoid high process temperatures, which lead to the development of austenite phases.

Microhardnesses of surface layers have higher values 
towards the machined surface. This is caused by thermal and mechanical impacts resulting from the removal of material by shearing phenomena, which is the main mechanism exerted in cutting processes.

It is concluded that the main benefits of hard machining processes are:

- reduction of manufacturing time by reducing the number of operations required to obtain the parts;

- elimination of some operations, such as: finishing operations by grinding; hole boring operations; electro-erosion machining;

- machining is carried out from a single orientationfixing of the blank, with an advantage on machining accuracy;

- easier to produce blanks are used, such as rectangular or cylindrical blanks;

- obtaining surfaces of higher quality and dimensional accuracy, with roughnesses of less than $1.6 \mu \mathrm{m}$ and good mechanical properties of the surface layers.

\section{ACKNOWLEDGEMENT}

This study was carried out within the project: Development of an integrated system for measuring some parameters of the machining processes on technological milling systems, no. CIPCS-2020-1581, funded by the University of Pitesti.

\section{REFERENCES}

1. Burek, J., Plodzien, M., Zylka, L., Sulkowicz, P., (2019). High-performance end milling of aluminum alloy: Influence of different serrated cutting edge tool shapes on the cutting force, Adv. Prod. Eng. Manag., 14(4), pp. 494-506.

2. Čilliková, M., Mičietová, A., Čep, R., Mičieta, B., Neslušan, M., Kejzlar, P., (2021). Asymmetrical Barkhausen Noise of a Hard Milled Surface, Materials, 14(5), pp. 1293.

3. Cui, X., Guo, J., Zhao, J., Yan, Y., (2015). Chip temperature and its effects on chip morphology, cutting forces, and surface roughness in high-speed face milling of hardened steel, Int. J. Adv. Manuf. Technol., 77(912), pp. 2209-2219.

4. Cui, X., Zhao, J., (2015). Effects of cutting parameters on chip morphology and tool wear in highspeed face milling of hardened steel, Proc Inst Mech. Eng. B. J. Eng. Manuf., 229(6), pp. 921 - 931.

5. Cui, X., Zhao, J., Tian, X., (2013). Cutting forces, chip formation, and tool wear in high-speed face milling of AISI H13 steel with CBN tools, Int. J. Adv. Manuf. Technol., 64, pp. 1737-1749.

6. Cui, X. B., Guo, J. X., Wang, X. Y., (2015). Cutting Force in High-Speed Face Milling AISI H13 Steel, Key Eng. Mater., 667, pp. 35 - 40.

7. Davim, J. P., (2010). Surface Integrity in Machining, Springer (London)
8. Davis, J. R., (1989). Metals handbook: Machining, 16, ASM International (USA)

9. Denkena, B., Köhler, J., Bergmann, B., (2015). Development of cutting-edge geometries for hard milling operations, CIRP J. Manuf. Sci. Technol., 8, pp. 43-52.

10. Dormer Pramet, (2020). Die \& Mold, Available from: https://www.dormerpramet.com/downloads/ pramet_diemold_metric_en.pdf, Accesed: 20/01/2021

11. Dombovari, Z., Stépán, G., (2015). On the bistable zone of milling processes, Philos. Trans. Royal Soc. A, 373 (2051).

12. Gaitonde, V., Karnik, S. R., Maciel, C. H. A., Rubio, J., Abrão, A. M., (2016). Machinability Evaluation in Hard Milling of AISI D2 Steel, Mater. Res.- Ibero. - Am. J, 19, pp. 360-369.

13. Grzesik, W., (2017). Advanced Machining Processes of Metallic Materials: Theory, Modelling and Applications, pp. 285-398, (second ed.), Elsevier, Netherlands (Amsterdam).

14. Hassanpour, H., Sadeghi, M. H., Rasti, A., Shajari, S., (2016). Investigation of surface roughness, microhardness and white layer thickness in hard milling of AISI 4340 using minimum quantity lubrication, J. Clean. Prod., 120, pp. 124-134.

15. Käsemodel, R. B., Souza, A. F., Voigt, R., Basso, I., Rodrigues, A., (2020). CAD/CAM interfaced algorithm reduces cutting force, roughness, and machining time in free-form milling, Int. J. Adv. Manuf. Technol., 107, pp. 1883-1900.

16. Koromat, S. (2010). Technical guide, Available from:https://www.sandvik.coromant.com/en-

gb/knowledge/pages/default.aspx, Accesed: 20/09/2021

17. Lakić, G. G., Kramar, D., Kopač, J., (2014). Metal cutting. Theory and applications, University of Ljubljana, Ljubljana.

18. Li, B., Zhang, S., Fang, Y., Zhang, J., Liu, Z., (2019). Deformation behaviour and texture evolution of martensite steel subjected to hard milling, Mater. Charact., 156, pp. 109881.

19. Li, B., Zhang, S., Wang, R., Fang, Y., (2019). Toward understanding of metallurgical behaviours in dry machining of hardened steel: phase transformation and surface oxidation, J. Mater. Res. Technol., 8, pp. 3811-3821.

20. Li, B., Zhang, S., Yan, Z., Jiang, D., (2018). Influence of edge hone radius on cutting forces, surface integrity, and surface oxidation in hard milling of AISI H13 steel, Int. J. Adv. Manuf. Technol., 95, pp. 11531164.

21. Li, B., Zhang, S., Yan, Z., Zhang, J., (2018). Effect of edge hone radius on chip formation and its microstructural characterization in hard milling of AISI H13 steel, Int. J. Adv. Manuf. Technol., 97, pp. 305318.

22. Li, B., Zhang, T., Zhang, S., (2018). Deep cryogenic treatment of carbide tool and its cutting performances in hard milling of AISI HI3 steel, Procedia CIRP, 71, pp. $35-40$. 
23. Liao, Z., la Monaca, A., Murray, J. W., Speidel, A., Ushmaev, D., Clare, A. T., Axinte, D., M'Saoubi, R., (2021). Surface integrity in metal machining - Part I: Fundamentals of surface characteristics and formation mechanisms, Int. J. Mach, 162 (103687).

24. Neslušan, M., Hrabovský, T., Cilliková, M., Micietová, A., (2015). Monitoring of Hard Milled Surfaces via Barkhausen Noise Technique, Procedia Eng., 132, pp. 472-479.

25. Neslušan, M., Micietová, A., Hadzima, B., Micieta, B., Kejzlar, P., Capek, J., Uricek, J., Pastorek, F., (2019). Barkhausen Noise Emission in Hard-Milled Surfaces, Materials, 12, pp.

26. Pimenov, D. Y., Hassui, A., Wojciechowski, S., Mia, M., Magri, A., Suyama, D. I., Bustillo, A., Królczyk, G. M., Gupta, M. K., (2019). Effect of the Relative Position of the Face Milling Tool towards the Workpiece on Machined Surface Roughness and Milling Dynamics, Appl. Sci., 9, pp. 817-842.

27. Ravi, S., Gurusamy, P., (2020). Experimental investigation to study the performance of cryogenic cooling in end milling of AISI P2O steel, Mater. Today: Proc., pp.

28. Riza, M., Adesta, E. Y. T., (2016). Cutting Temperature Investigation of AISI H13 in High-Speed End Milling, Int. J. Mater. Manuf., 1(1), pp. 27-34.

29. Shnfir, M., Olufayo, O. A., Jomaa, W., Songmene, V., (2019). Machinability Study of Hardened 1045 Steel When Milling with Ceramic Cutting Inserts, Materials, 12.

30. Smith, G. T., (2008). Cutting Tool Technology, Springer (London).

31. Soshi, M., Fonda, P., Kashihara, M., Yonetani, H., Yamazaki, K., (2013). A study on cubic boron nitride $(C B N)$ milling of hardened cast iron for productive and quality manufacturing of machine tool structural components, Int. J. Adv. Manuf. Technol., 65, pp. 14851491.

32. Stupakov, A., Neslušan, M., Perevertov, O., (2016). Detection of a milling-induced surface damage by the magnetic Barkhausen noise, J. Magn. Magn., 410, pp. 198-209.

33. Viswanathan, G., Praveen, R., Prabhu, L., Prakash, S., (2021). Evaluating the machining parameters for milling P2O HH mould steel using a specific end mill, Mater. Today: Proc. (Preprint).

34. Wang, M., Gao, L., Zheng, Y., (2014). An examination of the fundamental mechanics of cutting force coefficients, Int. J. Mach., 78, pp. 1-7.

35. Zhang, J., Zhang, S., Li, B., Wang, R., (2019). Investigation on plastic deformation behaviors in hard milling of H13 steel, J. Braz. Soc. Mech. Sci., 41, pp. 112.
Received: July 28, 2021 / Accepted: December 15, 2021 / Paper available online: December 20, 2021 (C) International Journal of Modern Manufacturing Technologies. 